\title{
UPAYA MENINGKATKAN MOTIVASI BELAJAR DI MASA PANDEMI COVID-19 MELALUI KONSELING KELOMPOK DENGAN STRATEGI SELF MANAGEMENT
}

\author{
Anita Dianasari, S.Pd. \\ SMK Negeri 1 Kemlagi \\ anitadianasari@gmail.com \\ Kusumaningtyas Febri Wijayanti \\ SMK PGRI 2 Jombang \\ kusumaningtyas05@gmail.com
}

\begin{abstract}
Abstrak
Peneliti berkeinginan untuk mengetahui signifikansi konseling kelompok dengan strategi self management terhadap motivasi belajar di masa pandemi covid-19 kelas XII MM di SMK Negeri 1 Kemlagi, Mojokerto. Sampel yang digunakan pada penelitian adalah 5 peserta didik yang mengalami penurunan motivasi belajar. Penelitian menggunakan 3 siklus yang indikator keberhasilannya baru dicapai pada siklus ke-3. Data hasil tindakan dijelaskan dengan analisis deskriptif kuantitatif dan analisis persentase. Hasil penelitian menunjukkan bahwa awalnya peserta didik memiliki motivasi belajar kurang, setelah dilakukan konseling kelompok dengan menerapkan strategi self management ada $40 \%$ peserta didik yang memiliki motivasi belajar sedang dan $60 \%$ peserta didik memiliki motivasi tinggi. Dengan demikian dapat disimpulkan bahwa ada signifikansi antara konseling kelompok dengan menerapkan strategi self management terhadap motivasi peserta didik dalam belajar pada masa pandemi kelas XII MM SMK Negeri 1 Kemlagi, Mojokerto.
\end{abstract}

Kata Kunci: motivasi belajar peserta didik, konseling kelompok, self management

\begin{abstract}
This research aimed to know the significant of group counseling with self management strategy toward student's learning motivation during pandemic time in class of XII MM 1, SMKN 1 Kemlagi, Mojokerto. The sampling used in this research were 5 students who had low learning motivation. The research used 3 cycles in which at the last cycle the indicator of succelfullnes was reached. The data was analized by using descriptive quantitative and percentage analysis. The result showed that at the beginning the students who had low learning motivation, after being treated with group counseling with self management strategy, there were $40 \%$ students who had medium motivation and $60 \%$ who had high motivation. Therefore, it can be concluded that there was a significant influence of group counseling by using self management strategy towards the students learning motivation in the pandemic time in the class of XII MM, SMKN 1 Kemlagi, Mojokerto.

Keywords: learning motivation, group councelling, self management strategy
\end{abstract}




\section{LATAR BELAKANG}

Pendidikan adalah investasi yang sangat penting bagi kemajuan bangsa. Proses pendidikan akan menghasilkan individu yang lebih berkompeten dari sebelumnya. Adapun hal yang berkaitan erat dengan pendidikan adalah belajar.

Pemerintah menganjurkan BDR saat pandemi dengan cara melaksanakan pembelajaran online. Tetapi mulai Agustus 2020, SMK Negeri 1 Kemlagi, Mojokerto mengeluarkan kebijakan untuk melakukan blended learning dengan memadukan pembelajaran daring dan luring. Tatap muka hanya dilakukan mata pelajaran produktif dengan memperhatikan protokol kesehatan. Selain mata pelajaran produktif, proses pembelajaran dilakukan full daring.

Proses pembelajaran daring ternyata menyebabkan beberapa peserta didik mengalami kejenuhan belajar yang berimbas kepada penurunan motivasi belajar. Turunnya motivasi belajar ditengarai dengan jarangnya mengakses Pembelajaran Jarak Jauh (PJJ), tidak mengumpulkan pekerjaan yang disampaikan guru, terlambat masuk ketika tatap muka dan tidak konsentrasi dalam menerima materi di sekolah.

Gejala masalah yang dibiarkan terusmenerus akan berimbas kepada turunnya prestasi belajar dan akan mengganggu tahap perkembangan peserta didik. Oleh sebab itu, motivasi belajar merupakan hal yang perlu dibangkitkan dalam proses pembelajaran (Ghullam Hamdu dan Lisa Agustina, 2011).

Nanang Hasan Susanto dan dan Cindy
Lestari (2018) menjelaskan teori motivasi prestasi oleh David Clarence McClelland yang menyatakan bahwa seseorang memiliki suatu simpanan energi yang bisa dikembangkan tergantung dari motivasi individu tersebut

Penelitian yang dilakukan oleh Rosa Siti Roseha Nuraini, Kasypul Anwar dan Aminah (2020) di SMP Negeri 4 Murung Pudak menunjukkan kalau konseling kelompok dengan strategi self management bisa menyelesaikan permasalahan motivasi belajar di sekolah tersebut. Selain berpengaruh terhadap peningkatan motivasi belajar, ternyata konseling kelompok yang dilakukan peneliti juga berimbas kepada peningkatan disiplin peserta didik.

Faiqotul Isnaini dan Taufik (2015) melakukan penelitian yang sama dengan menerapkan strategi self management pada konseling kelompok. Hasil penelitian tersebut menunjukkan bahwa strategi pengelolaan diri secara signifikan berpengaruh terhadap tingkat kedisiplinan.

Untuk memperbaiki motivasi belajar pada masa pandemi, konselor berkeinginan untuk melakukan penelitian dengan judul "Upaya Meningkatkan Motivasi Belajar di Masa Pandemi Covid-19 melalui Konseling Kelompok dengan Strategi Self Management".

\section{METODOLOGI}

Peneliti menggunakan rancangan PTBK yang terdiri dari 4 tahapan dalam 1 siklus. Penelitian dijadwalkan selama 3 siklus dengan rincian siklus 1 ada 3 pertemuan, siklus 2 sebanyak 3 pertemuan dan siklus 3 direncanakan ada 2 pertemuan. 
Yang menjadi populasi penelitian adalah 65 anak XII MM di SMK Negeri 1 Kemlagi. Sampel ditentukan dengan cara purposive sampling. Sampel penelitian adalah 5 orang yang memiliki motivasi belajar rendah.

Variabel bebas dalam penelitian yaitu konseling kelompok dengan menggunakan strategi self management, sedangkan variabel terikat dalam penelitian ini yaitu motivasi belajar peserta didik pada masa pandemi covid19. Instrumen penelitian yang digunakan adalah observasi dan skala pengukuran yang dikembangkan dengan prosedur content validity (Saifudin Azwar, 2017). Blue print skala motivasi belajar terdiri dari 48 pernyataan favourable dan unfavourable yang mengakomidir aspek motivasi menurut David Clarence McClelland.

Blue print kemudian disebar kepada peserta didik di luar populasi yang memiliki latar belakang dan karakter hampir sama dengan populasi. Data hasil uji coba kemudian dihitung validitasnya dengan SPSS for windows 25.0. Dari 48 pernyataan, ada 18 pernyataan yang dianggap gugur. Sehingga tersisa 30 pernyataan yang digunakan sebagai skala motivasi belajar. Pernyataan yang divalidasi tersebut, juga sudah dihitung angka reliabilitasnya dengan hasil 0,87 yang menunjukkan reliabilitasnya termasuk tinggi.

Data yang diambil saat penelitian dilakukan dengan pengamatan dan pengisian skala pengukuran. Skala pengukuran digunakan untuk menghitung hasil konseling dengan menerapkan strategi yang telah direncanakan pada siklus 1, 2 dan 3.

\section{HASIL PENELITIAN}

Pada siklus 1 konselor melakukan treatment kepada konseli melalui konseling kelompok dengan melakukan pengelolaan diri sendiri. Konseli diminta mengungkapkan gejala masalah yang menimpa mereka satu per satu, kemudian ditetapkan tujuan konseling kelompok yang sedang dilakukan. Sebelum menerapkan strategi, konselor terlebih dahulu memaparkan mengenai strategi self management menggunakan media video yang dibuat oleh peneliti dengan aplikasi Easy Sketch.

Pada siklus 1, proses konseling bisa dikatakan belum berhasil karena hanya ada 1 peserta didik yang mengalami perubahan motivasi, yaitu dari motivasi rendah ke motivasi sedang. 4 peserta didik yang lain masih belum mengalami perubahan motivasi belajar. Hal ini dimungkinkan karena peserta didik masih bingung dalam menerapkan strategi yang sudah disepakati.

Pada siklus 2, konselor memperjelas lagi mengenai strategi self management. Tahapan stimulus control dan self reward yang belum dipaparkan dan diterapkan pada siklus 1, akan dilakukan pada siklus 2. Hasil siklus 2 menunjukkan kemajuan yang baik, yaitu $20 \%$ mengalami kenaikan motivasi dari motivasi rendah menjadi sedang dan $40 \%$ peserta didik masuk dalam kriteria motivasi tinggi. Biarpun sudah ada beberapa peserta didik yang mengalami perubahan motivasi, tetapi indikator keberhasilan juga belum tercapai. Oleh karena itu dilakukan siklus 3.

Siklus 3 dilakukan pendalaman strategi konseling kelompok dengan strategi self 
Jurnal HELPER, Vol 37 No 1 (2020) 07 - 11

Bimbingan dan Konseling Universitas PGRI Adi Buana Surabaya

ISSN: 02162938

management dengan sebelumnya diputarkan

film yang bisa memberikan inspirasi kepada peserta didik. Film tersebut bercerita mengenai seseorang yang memiliki motivasi belajar rendah yang kemudian dimarahi oleh sang guru. Kemarahan guru tersebut menjadi cambuk tersendiri bagi anak dalam film tersebut. Sehingga anak itu bisa merubah kebiasaan yang kurang baik dari malas belajar menjadi lebih rajin dalam belajar.

Setelah menayangkan film yang memiliki cerita hampir sama dengan yang dialami oleh sampel penelitian, konselor mengajak berdiskusi dengan mengaitkan antara film yang sudah ditayangkan dengan penerapan strategi pengelolaan diri. Salah satu peserta didik berpendapat bahwa self management ternyata memiliki andil yang besar dalam keberhasilan seseorang, karena yang bisa mengatur atau mengelolah diri adalah orang itu sendiri. Dengan memiliki pandangan yang positif seperti itu, peneliti sebagai konselor memanfaatkan momen tersebut untuk meminta peserta didik mematuhi pernyataan kegiatan sebagai pengganti kegiatan yang kurang baik yang dilakukan selama ini.

Hasil dari penelitian siklus 3 menunjukkan bahwa indikator keberhasilan tercapai dengan baik. Kriteria indikator keberhasilan yaitu: (1) apabila rata-rata hasil skala pengukuran menunjukkan peningkatan motivasi peserta didik lebih dari $75 \%$ (2) apabila rata-rata hasil skala pengukuran menunjukkan kurang dari $75 \%$ konseli bermotivasi belajar rendah. Treatment pada siklus 3 menunjukkan bahwa dari kelima

sampel penelitian sudah mengalami perubahan motivasi belajar yang terdiri dari $60 \%$ sudah mengalami perubahan ke motivasi tinggi dalam belajar dan $40 \%$ berubah menjadi motivasi sedang. Sehingga, bisa disimpulkan bahwa ada signifikansi antara konseling kelompok dengan menerapkan strategi self management terhadap motivasi belajar pada masa pandemi bagi peserta didik kelas XII MM SMK Negeri 1 Kemlagi, Mojokerto

\section{KESIMPULAN}

Mulai Maret 2020 pemerintah menetapkan covid-19 sebagai pandemi dan mengharuskan peserta didik Belajar Dari Rumah (BDR). Akibatnya beberapa peserta didik mengalami masalah psikologis, salah satunya yaitu penurunan motivasi belajar. Pada tanggal 23 September 2020 peneliti melakukan pengamatan di kelas XII di SMK Negeri Kemlagi dan hasilnya menunjukkan bahwa ada 16 dari 65 peserta didik yang mengalami penurunan motivasi belajar.

Hasil purposive sampling didapatkan 5 sampel penelitian dengan tingkat motivasi belajar paling rendah. Treatment dilakukan dalam 3 siklus dan 4 tahapan yang meliputi tahap perencanaan, tindakan, pengamatan dan refleksi. Hasil siklus 1 dan 2 menunjukkan belum tercapainya indikator keberhasilan. Penelitian baru mencapai indikator keberhasilan pada siklus 3, yaitu $60 \%$ peserta didik sudah masuk kategori motivasi tinggi dalam belajar dan $40 \%$ peserta didik masuk kriteria motivasi sedang. Dengan memperhatikan data hasil penelitian, bisa disimpulkan bahwa konseling kelompok yang menerapkan strategi self 
Jurnal HELPER, Vol 37 No 1 (2020) 07 - 11

Bimbingan dan Konseling Universitas PGRI Adi Buana Surabaya ISSN: 02162938

management memiliki signifikansi terhadap motivasi belajar kelas XII MM di SMK Negeri 1 Kemlagi, Mojokerto.

\section{SARAN}

Pada penelitian kali ini, konselor menyarankan beberapa hal, antara lain:

1. Peserta didik yang memiliki masalah psikologis, bisa melakukan konseling ke guru BK sebagai tenaga profesional untuk mereduksi gejala masalah yang dialami.

2. Guru BK di SMK Negeri 1 Kemlagi, Mojokerto agar lebih mengoptimalkan konseling kelompok dalam pembelajaran dengan memanfaatkan dinamika kelompok yaitu kemampuan menyampaikan pertanyaan, pendapat, saran, dll.

3. Bagi peneliti lain yang tertarik dengan tema penelitian ini atau permasalahan lain yang dihadapi peserta didik pada masa pandemi, bisa dilakukan penelitian dengan pendekatan dan strategi lain yang lebih efektif.

\section{DAFTAR PUSTAKA}

Azwar, Saifuddin. (2017). Metode Penelitian Psikologi Edisi 2. Yogyakarta: Pustaka Pelajar.

Hamdu, Ghullam dan Lisa Agustina. (2011). Pengaruh Motivasi Belajar Siswa terhadap Prestasi Belajar IPA di Sekolah Dasar. Jurnal Penelitian Pendidikan, Vol. 12 No, 1.

Isnaini, Faiqotul dan Taufik. (2015). Strategi Self Management untuk Meningkatkan Kedisiplinan Siswa. Jurnal Penelitian Humaniora, Vol. 16 No. 02.

Nuraini, Rosa Siti Roseha, Kasypul Anwar dan Aminah. (2020). Meningkatkan Motivasi Belajar dengan Konseling Kelompok dengan Teknik Self-Management di SMP Negeri 4 Murung Pudak. Jurnal Mahasiswa BK An-Nur, Vol. 6 No. 1.

Nursalim, Mochamad. 2013. Strategi dan Intervensi Konseling. Jakarta: Akademia Permata.

Susanto, Nanang Hasan dan Cindy Lestari. (2018). Mengurai Problematika Pendidikan Nasional Berbasis Teori Motivasi Abraham Maslow dan David McMclelland. Jurnal Lembaran Ilmu Kependidikan, Vol. 47 No. 1.

Winkel W. S. dan M. M. Sri Hastuti. (2015). Bimbingan dan konseling di Institusi Pendidikan. Yogyakarta: Media Abadi. 